natureresearch

Check for updates

\title{
OPEN Author Correction: OutPredict: multiple datasets can improve prediction of expression and inference of causality
}

Jacopo Cirrone, Matthew D. Brooks, Richard Bonneau, Gloria M. Coruzzi \& Dennis E. Shasha

Correction to: Scientific Reports https://doi.org/10.1038/s41598-020-63347-3, published online 22 April 2020

The Acknowledgements section in this Article is incomplete.

“The authors gratefully acknowledge funding from the following sources: NIH NIGMS Grant GM032877 to G.M.C. and D.E.S., NSF-PGRP IOS-1339362 to G.M.C. and D.E.S., an NIH NIGMS Fellowship 1F32GM116347 to M.D.B., and a Plant Genomics Grant from the Zegar Family Foundation (A160051)."

should read:

"The authors gratefully acknowledge funding from the following sources: NIH RO1 GM121753 to G.M.C. and D.E.S., NIH NIGMS Grant GM032877 to G.M.C. and D.E.S., NSF-PGRP IOS-1339362 to G.M.C. and D.E.S., an NIH NIGMS Fellowship 1F32GM116347 to M.D.B., and a Plant Genomics Grant from the Zegar Family Foundation (A160051)."

(i) Open Access This article is licensed under a Creative Commons Attribution 4.0 International License, which permits use, sharing, adaptation, distribution and reproduction in any medium or format, as long as you give appropriate credit to the original author(s) and the source, provide a link to the Creative Commons license, and indicate if changes were made. The images or other third party material in this article are included in the article's Creative Commons license, unless indicated otherwise in a credit line to the material. If material is not included in the article's Creative Commons license and your intended use is not permitted by statutory regulation or exceeds the permitted use, you will need to obtain permission directly from the copyright holder. To view a copy of this license, visit http://creativecommons.org/licenses/by/4.0/.

(c) The Author(s) 2020 